\title{
Metabolic Response to Growth Hormone Admin- istration, with Particular Reference to the Occurrence of Hypercalcuria
}

\author{
Mrahael F. Bryson ${ }^{[0]}$, Gilbert B. Forbes, G. H. Amirhakimi, and Julio C. Reina \\ Departments of Pediatrics and Radiation Biology, University of Rochester School of Medicine, Rochester, New York, USA
}

\section{Extract}

The effect of human growth hormone ( $\mathrm{GH}$ ) administration (5 mg daily) was studied in 12 children with short stature, in an attempt to elucidate the cause of the hypercalcuria which so commonly occurs at the initiation of GH therapy. Complete metabolic balances were determined for $\mathrm{Ca}, \mathrm{P}, \mathrm{N}, \mathrm{Na}, \mathrm{K}$, and $\mathrm{Cl}$; and urine was analyzed for hydroxyproline, stable $\mathrm{Sr}, \mathrm{Pb}, \mathrm{Mg},{ }^{137} \mathrm{Cs}, \mathrm{F}$, and creatinine. Some subjects had determinations of basal metabolic rate (BMR) and of ultrafiltrable serum $\mathrm{Ca}$. In keeping with the reports of others, levels of $\mathrm{N}, \mathrm{P}, \mathrm{K}, \mathrm{Na}$, and $\mathrm{Cl}$ in urine all declined, as did that of ${ }^{137} \mathrm{Cs} ; \mathrm{Mg}$ excretion fell slightly.

Ten of the 12 children with short stature (6 of whom had subnormal plasma GH responses to a variety of stimuli) had hypercalcuria; 3 of these had an increase in urine $\mathrm{Ca}$ in the face of a low Ca diet $(170 \mathrm{mg} / 24 \mathrm{hr})$. Fecal Ca declined in some subjects and rose in others. Ultrafiltrable serum Ca did not change.

A majority of the subjects showed an increase in the urinary excretion of $\mathrm{F}, \mathrm{Sr}, \mathrm{Pb}$, and hydroxyproline.

The effect of the hormone was also studied in three patients with idiopathic hypoparathyroidism; two of these responded with an increase in urine Ca.

The magnitude of the rise in urine Ca could not be correlated with changes in BMR, changes in creatinine clearance, or changes in $\mathrm{Na}$ excretion; it was positively correlated with the increases in $\mathrm{Sr}$ and $\mathrm{Pb}$ in urine.

\section{Speculation}

We have evidence that the hypercalcuria accompanying $\mathrm{GH}$ administration is not due to increased gastrointestinal absorption, alterations in serum $\mathrm{Ca}$, or changes in metabolic rate or renal function; nor is it mediated via parathyroid activity. These considations, plus the fact that the hypercalcuria is accompanied by hydroxyprolinuria and an increase in the urinary excretion of three "bone seekers" ( $\mathrm{Sr}, \mathrm{Pb}$, and $\mathrm{F}$ ), lead us to postulate that the hormone enhances bone resorption, either per se or via "sulfation factor."

\section{Introduction}

Normocalcemic hypercalcuria commonly occurs at the onset of growth hormone $(\mathrm{GH})$ therapy. This response stands in contrast to that of $\mathrm{P}, \mathrm{N}, \mathrm{K}, \mathrm{Na}$, and $\mathrm{Cl}$, all of which are excreted in lesser amounts. Whereas the metabolic balance of these elements becomes strongly positive, the hypercalcuria can be so intense as to re- 
sult in a negative Ca balance. As GH therapy is continued, however, the level of $\mathrm{Ca}$ in urine eventually returns to normal.

The reason for the aberrant behavior of $\mathrm{Ca}$ in response to $\mathrm{GH}$ administration is not known. In addition to having been observed in children with GH deficiency, hypercalcuria has been noted in normal children and adults, and in patients with such diverse conditions as Turner's syndrome [10], acromegaly [22], primordial dwarfism [39], dwarfism with elevated plasma GH levels (Laron dwarfs) [21], resistant rickets, renal osteodystrophy [16], and osteoporosis [13, 30]. However, Vest et al. [36] found hypercalcuria in only half of the normal infants whom they studied; Villee et al. [37] failed to find it in one child with progeria, as did Root and Oski [27] in two of three senile adults.

A commonly held assumption, based largely on the early studies of Shepard et al. [31] and Henneman et al. [14] is that the hypercalcuria is secondary to increased gastrointestinal absorption. Fraser and Harrison's [11] work with rats suggests that it is mediated via the parathyroid glands. The fact that urinary hydroxyproline excretion also rises in response to $\mathrm{GH}$ administration $[9,28,30,39]$ suggests that bone turnover is enhanced, and both Schwartz et al. [29, 30] and we [9] have put forward the postulate that the hormone acts to increase bone resorption.

The following experimental results are offered in an attempt to clarify this question.

\section{Subjects and Methods}

The subjects were 12 children, aged 4 to 18 years, under investigation for short stature (Table I). Eight of them had subnormal plasma growth hormone responses to both insulin and arginine administration (4 $\mathrm{ng} / \mathrm{ml}$ or less); one had an equivocal response to both agents; and three had a good response to arginine but not to insulin. The table illustrates the variation in plasma $\mathrm{GH}$ response to the various provocative agents which we used. Of the 12 subjects only 6 failed to respond to any of the agents $(R S, D L, P D, S B, L T$, $J W)$.

In addition, there were three patients with idiopathic hypoparathyroidism.

Studies were carred out at the Clinical Research Center; a constant, weighed diet was offered plus distilled water ad libitum; fecal collection periods were marked with carmine; and the patients were ambulatory within the confines of the ward. Balance periods were $4-6$ days in duration ( 8 days in one subject), and a 4-day fore period on diet preceded the first balance period (6 days in the case of low Ca diet). None had a significant change in body weight.

Nine subjects were offered a diet which approximated their usual daily intake; three were given a diet low in $\mathrm{Ca}$ but adequate in other respects. Two subjects $(P D$ and $L T$ ) were kept on thyroid medication during the study, and subject $J E$ continued to receive pitressin.

Table I. Subject description

\begin{tabular}{|c|c|c|c|c|c|c|c|c|c|c|c|}
\hline \multirow[b]{2}{*}{ Subject } & \multirow{2}{*}{ Sex } & \multirow{2}{*}{$\begin{array}{c}\text { Age, } \\
\text { yr-mo }\end{array}$} & \multirow{2}{*}{$\underset{\mathrm{cm}}{\text { Height, }}$} & \multirow{2}{*}{ Weight, } & \multirow{2}{*}{$\begin{array}{l}\text { Height } \\
\text { age, } \\
\text { yr-mo }\end{array}$} & \multirow{2}{*}{$\begin{array}{l}\text { Bone } \\
\text { age, } \\
\text { yr-mo }\end{array}$} & \multirow{2}{*}{$\begin{array}{l}\text { Pre Rx } \\
\text { growth rate, } \\
\mathrm{cm} / \mathrm{mo}\end{array}$} & \multicolumn{3}{|c|}{ Maximum plasma GH, ng/ml } & \multirow[b]{2}{*}{ Remarks } \\
\hline & & & & & & & & Insulin & $\begin{array}{l}\text { Argi- } \\
\text { nine }\end{array}$ & Other & \\
\hline$R S$ & $\mathrm{M}$ & $17-8$ & 128 & 41.9 & $7-9$ & $10-0$ & $0.25(156)^{1}$ & $<1$ & $<1$ & $4,{ }^{2} 1^{3}$ & $\downarrow$ Thyroid, normal puberty \\
\hline$D L$ & $F$ & $9-10$ & 104 & 15.3 & $4-3$ & $3-6$ & $0.25(72)$ & 3.5 & 2 & $3^{2}$ & Inappropriate antiduretic hormone \\
\hline$P D$ & M & $9-7$ & 110 & 16.8 & $5-0$ & $4-6$ & $0.67(6)$ & $<1$ & 1.4 & & $\downarrow$ Thyroid stimulating hormone, \\
\hline$S B$ & $M$ & $15-0$ & 142 & 54.2 & $10-3$ & $13-9$ & $0.30(92)$ & 2 & 2.2 & $3.5^{2}$ & poor response to metyratone \\
\hline$E B$ & $\mathrm{M}$ & $17-8$ & 138 & 33.2 & $9-6$ & $14-6$ & $0.54(24)$ & 2.5 & 17.9 & $2.3,2 \quad 4.9^{4}$ & \\
\hline$R C$ & $\mathrm{M}$ & $3-11$ & 87 & 10.6 & $2-0$ & $2-0$ & $0.42 \quad(24)$ & 3.7 & 4.6 & $2.5,^{4} \quad 8.7^{5}$ & $\begin{array}{l}\text { Mild inflammation, duodenal mu- } \\
\text { cosa }\end{array}$ \\
\hline$L T$ & $\mathrm{~F}$ & $15-8$ & 142 & 37.1 & $10-6$ & $13-6$ & $0.42(24)$ & 1.0 & $<1$ & $1.9,4<1^{6}$ & $\downarrow$ Thyroid, early puberty \\
\hline$D T$ & $\mathrm{M}$ & $13-9$ & 138 & 35.0 & $9-6$ & $10-0$ & $0.31 \quad(105)$ & $<1$ & 22 & & \\
\hline$J E$ & M & $9-10$ & 116 & 23.5 & $5-9$ & $4-6$ & $0.32(49)$ & $<1$ & $<1$ & $6.9,78.6^{8}$ & Histiocytosis, diabetes insipidus \\
\hline$J W$ & $\mathrm{~F}$ & $15-10$ & 141 & 54.6 & $10-6$ & $13-0$ & $0.31 \quad(8)$ & $<1$ & 1.2 & $<1^{9}$ & Scarred right kidney, reduced \\
\hline$S H$ & M & $12-10$ & 136 & 30.8 & $9-0$ & $11-0$ & 0.35 (94) & 5.3 & 4.2 & $<1^{4}$ & $\{$ function; diabetic glucose tol- \\
\hline$T C$ & M & $6-2$ & 93 & 9.9 & $2-6$ & $3-0$ & $0.33 \quad(36)$ & 4 & 16.4 & & erance; prepubescent \\
\hline \multicolumn{5}{|c|}{$\begin{array}{l}{ }^{1} \text { Observation period, } \\
{ }^{2} \text { Piromen, } 0.5 \mu \mathrm{g} / \mathrm{kg} \text {. } \\
{ }^{3} \text { Exercise. } \\
{ }^{4} \text { Sleep. }\end{array}$} & \multicolumn{6}{|c|}{$\begin{array}{l}{ }^{6} \text { L-dopa, } 250 \mathrm{mg} \text {. } \\
{ }^{7} \text { Fasting sample, age } 6 \text {. } \\
{ }^{8} \text { Pitressin, age } 6 . \\
{ }^{9} \text { Glucose tolerance. }\end{array}$} & \\
\hline
\end{tabular}


Human growth hormone [40] was given intramuscularly in a dose of $5 \mathrm{mg}$ daily.

Analytical methods were as follows: $\mathrm{Ca}, \mathrm{P}$, and $\mathrm{N}$ assays in an automatic analyzer [41]; serum ultrafiltrable Ca by the method of Toribara et al. [35] using the atomic absorption spectrophotometer; stable Sr [43] and $\mathrm{Mg}$ in this same instrument; $\mathrm{Pb}$ by emission spectrophotometry [44]; $\mathrm{F}$ by the method of Smith and Gardner [33, 45]; hydroxyproline by the method of Prockop and Udenfriend [25]; cesium-137 by scintillation counting in a low background room; creatinine, $\mathrm{Na}, \mathrm{K}, \mathrm{Cl}$, and BMR by standard methods.

\section{Results}

Urine calcium. Seven of the nine subjects on normal diet manifested an increase in excretion of $\mathrm{Ca}$ in urine in response to growth hormone administration (Table II). In six subjects the rise in urine $\mathrm{Ca}$ began on the 1st day of GH treatment; in the seventh it began on the 2 nd day. Urine Ca excretion progressively rose during the treatment period in three of the subjects; in the other four excretion reached a maximum on the 2 nd or 3 rd clay, after which it either remained fairly constant or fell slightly. In four subjects we were able to continue urine collections for several days after $\mathrm{GH}$ was discontinued; urine $\mathrm{Ca}$ values fell to control levels by the $3 \mathrm{rd}$ to 4 th day in two subjects but were still elevated on the 5 th day in the other two.

The magnitude of the hypercalcuria varied among these seven subjects. When the average daily excretion for the entire $\mathrm{GH}$ period is compared to that of the immediately preceding control period, the increase ranged from 1.27 to 5.90 -fold (average 2.31 ). The highest single daily value during the GH period was 7.5 times base line (subject $P D$ ). And, as noted in Table II, two of the nine subjects on normal diet failed to show a change in the excretion of $\mathrm{Ca}$ in urine.

Each of the three subjects on low Ca diet showed an increase in urine Ca excretion, the average being 2.58 times the control value. The rise began on the 2 nd day of GH treatment in all three subjects; it reached a maximum on the 3rd day in one subject, while the other two showed a progressive rise. In two of these subjects the peak value (170 $\mathrm{mg} \mathrm{Ca} / 24 \mathrm{hr}$ ) approximated the dietary intake.

The six subjects who showed a plasma GH response to one or more stimuli had a somewhat smaller increase in urine $\mathrm{Ca}$ ( 1.77 times base line) than the six who did not (2.55 times), but this difference is not significant $(P>0.30)$.

Fecal calcium. These values are listed in Table III. As expected, there was some variation during control periods. When the daily fecal loss during the $\mathrm{GH}$ period is compared with the immediately preceding control period, the observed changes ranged from +125 to $-110 \mathrm{mg} / 24 \mathrm{hr}$. Four subjects showed a decrease in fecal $\mathrm{Ca}$, two an increase, while for the remaining five the change was insignificant (less than $40 \mathrm{mg} / 24 \mathrm{hr}$ ). The overall average change was $-7 \mathrm{mg} / 24 \mathrm{hr}$ for these 11 subjects $(S B$ is excluded from these calculations because of inadequate stool collection in second control period).

In Figure 1 the change in urine $\mathrm{Ca}$ is plotted against the change in fecal Ca observed during GH treatment.

Table II. Changes in urinary excretion

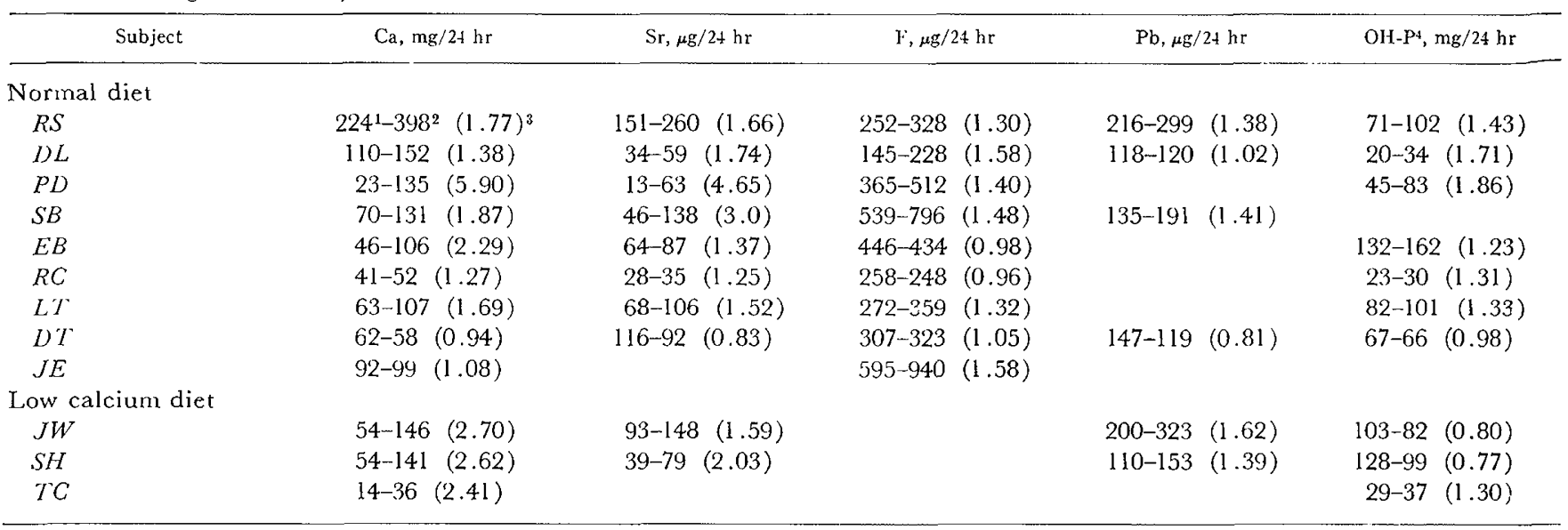

\footnotetext{
${ }^{1}$ Control period, mean. $\quad{ }^{3}$ Ratio of $\mathrm{GH} /$ control periods.

${ }^{2} \mathrm{GH}$ period, mean. $\quad 4 \mathrm{OH}-\mathrm{P}$ : hydroxyproline.
} 
Table III. Fecal Ca/P (mg/24 hr)

\begin{tabular}{lccccc}
\hline Subject & $\begin{array}{c}\text { Control } \\
\text { I }\end{array}$ & $\begin{array}{c}\text { Control } \\
\text { Il }\end{array}$ & GH & $\begin{array}{c}\text { Post GH } \\
\text { control }\end{array}$ & $\begin{array}{c}\text { Ca/P in diet, } \\
\mathrm{mg} / 24 \mathrm{hr}\end{array}$ \\
\hline$R S$ & $670 / 370$ & $700 / 405$ & $590 / 355$ & & $1210 / 1545$ \\
$D L$ & $310 / 300$ & $360 / 280$ & $350 / 230$ & & $630 / 940$ \\
$P D$ & & $420 / 290$ & $545 / 290$ & $555 / 245$ & $560 / 745$ \\
$S B$ & $560 / 350$ & 1 & $600 / 370$ & & $800 / 1320$ \\
$E B$ & $475 / 230$ & $445 / 280$ & $375 / 235$ & $470 / 270$ & $940 / 1475$ \\
$R C$ & $615 / 315$ & $525 / 250$ & $520 / 245$ & $515 / 275$ & $480 / 800$ \\
$L T$ & & $350 / 195$ & $370 / 220$ & $350 / 185$ & $560 / 1000$ \\
$D T$ & $1030 / 705$ & $990 / 610$ & $880 / 590$ & & $1050 / 990$ \\
$J E$ & & $505 /$ & $605 /$ & & $780 /-$ \\
$J W$ & $155 / 165$ & $195 / 160$ & $125 / 110$ & & $165 / 955$ \\
$S H$ & $150 / 155$ & $205 / 235$ & $225 / 225$ & & $160 / 1030$ \\
$T C$ & $140 / 130$ & $115 / 120$ & $150 / 135$ & & $170 / 370$ \\
& & & & & \\
\hline
\end{tabular}

${ }^{1}$ Incomplete collection.

There is no obvious relationship between these two variables.

Comparison of $\mathrm{Ca}$ and $\mathrm{P}$ excretion. Urine $\mathrm{P}$ excretion fell in six subjects, increased slightly in one, and did not change appreciably in the remaining four in response to $\mathrm{GH}$ treatment. The average excretion during the $\mathrm{GH}$ period was $88 \%$ of that for the control period. Fecal $\mathrm{P}$ decreased in four subjects, while six showed an insignificant change (less than $40 \mathrm{mg} / 24$ $\mathrm{hr}$ ); the average change was $-19 \mathrm{mg} / 24 \mathrm{hr}$ (Table III).

There was no obvious relationship between the magnitude of the change in urine $\mathrm{Ca}$ and the change in urine $P(r-0.17)$, nor was there one between the change in urine $P$ and the change in fecal $P$.

Urine $S r, P b, F$. These elements were assayed because they reside principally in the skeleton and are known as bone seekers [32]. During the control periods (the subjects being given distilled water), the average daily excretion of stable $\mathrm{Sr}$ among these subjects

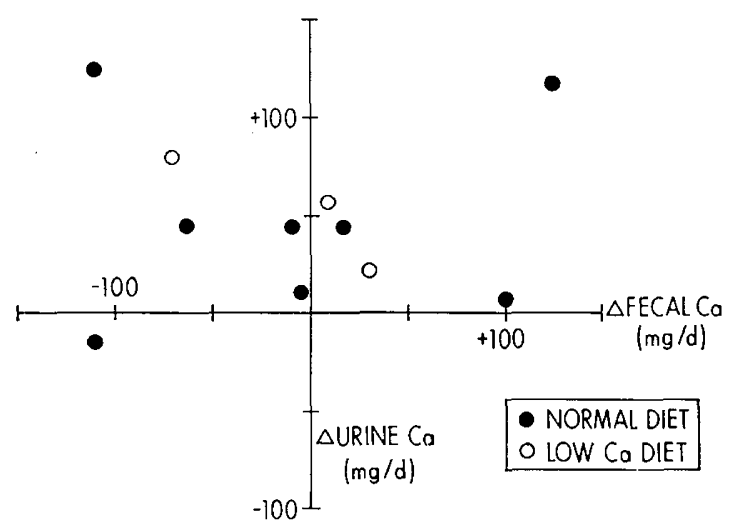

Fig. 1. Plot of change in urine $\mathrm{Ca}(\mathrm{mg} / 24 \mathrm{hr})$ versus change in fecal $\mathrm{Ca}(\mathrm{mg} / 24 \mathrm{hr})$ during $\mathrm{GH}$ treatment. ranged from 13 to $151 \mu \mathrm{g}$, that of $\mathrm{Pb}$ was $110-216 \mu \mathrm{g}$, and the value for $\mathrm{F}$ was $145-595 \mu \mathrm{g}$ (Table II). Strontium excretion was correlated with $\mathrm{Ca}(r+0.68)$, but not with $\mathrm{F}$ or $\mathrm{Pb}$ excretion in the control periods.

The relationships between the change in $\mathrm{Ca}$ in urine and the changes in urine $\mathrm{Sr}, \mathrm{Pb}$, and $\mathrm{F}$ are illustrated in Figure 2. Of those subjects (10 in number) who sustained a rise in urine $\mathrm{Ca}$ excretion during $\mathrm{GH}$ administration, $9 / 9$ showed an increase in $\mathrm{Sr}$ excretion, $4 / 5$ a rise in $\mathrm{Pb}$ excretion, and $5 / 7$ a rise in $\mathrm{F}$ excretion. Two subjects $(D T$ and $J E)$ showed no change in urine $\mathrm{Ca}$. One of these showed a slight decrease in urine $\mathrm{Sr}$ and $\mathrm{Pb}$, and no change in $\mathrm{F}$ excretion. The other showed an increase in urine $F$, but there are no data on $\mathrm{Sr}$ and $\mathrm{Pb}$ for this subject.

In comparison with the immediately preceding control period, GH administration produced increases of excretion in urine of 1.96-fold for $\mathrm{Sr}$, 1.27-fold for $\mathrm{Pb}$, and 1.29-fold for $\mathrm{F}$. When the changes in $\mathrm{Sr}, \mathrm{Pb}$, and $\mathrm{F}$ excretion are compared with urine Ca changes for those same subjects, the increase in $\mathrm{Sr}$ excretion was only $88 \%$ as great as the increase in $\mathrm{Ca}$ excretion $(N=10)$, $\mathrm{Pb}$ was $68 \%$ of that for $\mathrm{Ca}(N=6)$, and $\mathrm{F}$ was $65 \%$ of that for $\mathrm{Ca}(N=9)$. Hence the increase in urinary excretion of these three bone seekers was somewhat less than the increase in urine $\mathrm{Ca}$. The same was true for hydroxyproline (OH-P), for the relative change in excretion of this compound was only $55 \%$ as great as the change in excretion of $\mathrm{Ca}$ in urine $(N=10)$.

Urinary excretion of other substances. The changes in urinary excretion of $\mathrm{P}, \mathrm{Mg}, \mathrm{N}, \mathrm{K},{ }^{137} \mathrm{Cs}, \mathrm{Na}$, and $\mathrm{Cl}$ during the $\mathrm{GH}$ period relative to control values are illustrated in Figure 3, along with those elements $(\mathrm{Ca}$,

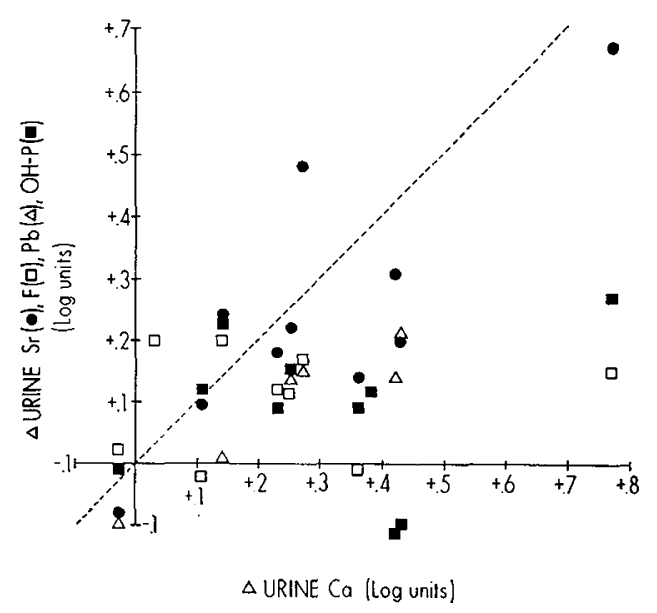

Fig. 2. Relative changes in excretion of $\mathrm{Sr}, \mathrm{Pb}$, and $\mathrm{F}$ in urine versus relative change in urine $\mathrm{Ca}$ during $\mathrm{GH}$ treatment (double $\log$ scale). 


\section{CHANGE IN URINARY EXCRETION}

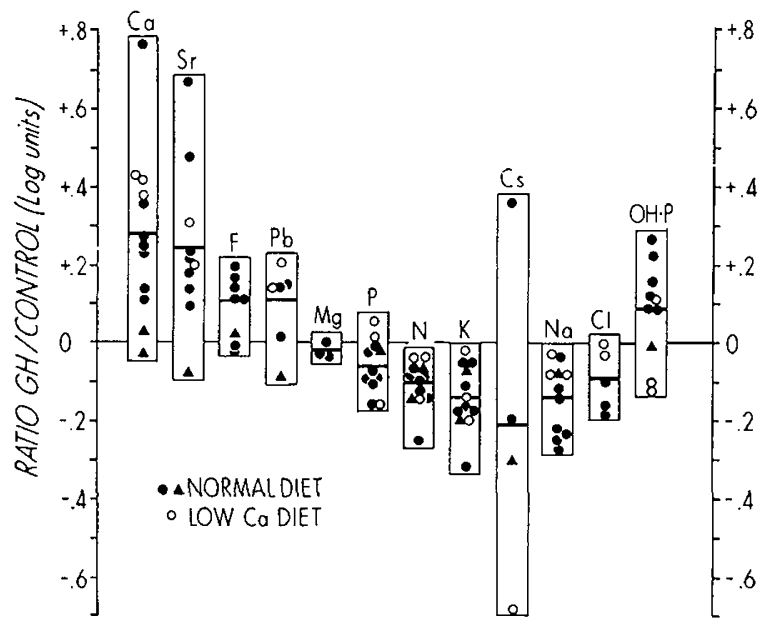

Fig. 3. Ratio of excretion in urine during $\mathrm{GH}$ period to that during control period of the various substances assayed. Ordinate in $\log$ units $(+0.3$ value indicates doubling of the excretion, -0.3 a halving). Symbols: subjects on normal diet with $(\bullet)$ and without (A) hypercalcuria, those on low Ca diet (O); average of log values $(-)$.

$\mathrm{Sr}, \mathrm{F}, \mathrm{Pb}, \mathrm{OH}-\mathrm{P}$ ) already tabulated in Table II. (The values in Figure 3 represent the average daily excretions during the $\mathrm{GH}$ period as multiples-or fractions as the case may be-of the average for the control period immediately preceding.) As the graph shows, these 12 urinary components fall into three general groups: the excretion of $\mathrm{Ca}, \mathrm{Sr}, \mathrm{Pb}$, and $\mathrm{F}$ tends to increase when GH is given (as does hydroxyproline); $\mathrm{N}, \mathrm{K},{ }^{137} \mathrm{Cs}, \mathrm{Na}$, and $\mathrm{Cl}$ tend to decrease; and $\mathrm{P}$ and $\mathrm{Mg}$ occupy an intermediate position. An important difference among these three groups of elements is their distribution within the body: members of the first group reside principally in the skeleton; those of the second group are located for the most part in the soft tissue. Phosphorus and $\mathrm{Mg}$ are intermediate between these two extremes, the skeletal component being 85 and 66\%, respectively, of the entire (adult) body content [38] (the "skeleton" in this context includes marrow and periosteum, so the true values are somewhat lower). Hence the excretory behavior of a given substance in response to $\mathrm{GH}$ administration reflects its location within the body.

The excretion of ${ }^{137} \mathrm{Cs}$ was measured because of the fact that, although this element (a fallout product) is distributed in the body much like $\mathrm{K}$, it is not subject to the same degree of homeostatic control. Excretion declined in three of the four subjects; the somewhat erratic behavior depicted in Figure 3 probably reflects the low precision of the assay for the observed excretion range of $10-20 \mathrm{pCi} / 24 \mathrm{hr}$.

Hydroxyproline excretion rose in 7 of the 10 subjects in whom this substance was determined; of the 3 subjects not showing a rise in excretion, 2 were on low Ca diet, and the 3rd did not have hypercalcuria.

We attempted to interrelate the changes in excretion in urine of these constituents. As depicted above (Fig. 2 ), there was good correspondence between the magnitude of the increases in urine of $\mathrm{Ca}$ and $\mathrm{Sr}(r+0.86)$ and between the increases in urine of $\mathrm{Ca}$ and $\mathrm{Pb}(r+$ 0.90). However, the increment in Ca excretion failed to show a significant correlation with the changes in urine F, P, N, K, Na, or OH-P. There was an inverse correlation $(r-0.82)$ between the rise in OH-P and the decrease in $\mathrm{N}$ in urine. As expected, the changes in $\mathrm{K}, \mathrm{N}$, and $\mathrm{Na}$ in urine were all correlated ( $r$ significant at the 0.05 level).

Serum ultrafiltrable calcium and magnesium. As a check on the possibility that the hypercalcuria accompanying GH administration could have been due to changes in the concentration of ultrafiltrable $\mathrm{Ca}$ in serum, serial serum samples were assayed in four subjects, all of whom showed a rise in urine calcium. The results are shown in Figure 4. There are no consistent trends to be seen.

However, ultrafiltrable serum Mg did decrease in all four subjects in response to $\mathrm{GH}$ administration, as did total serum $\mathrm{Mg}$. In contrast to the behavior of $\mathrm{Ca}$, urinary excretion of $\mathrm{Mg}$ declined slightly (Fig. 3).

Observations on BMR. Serial runs in the control

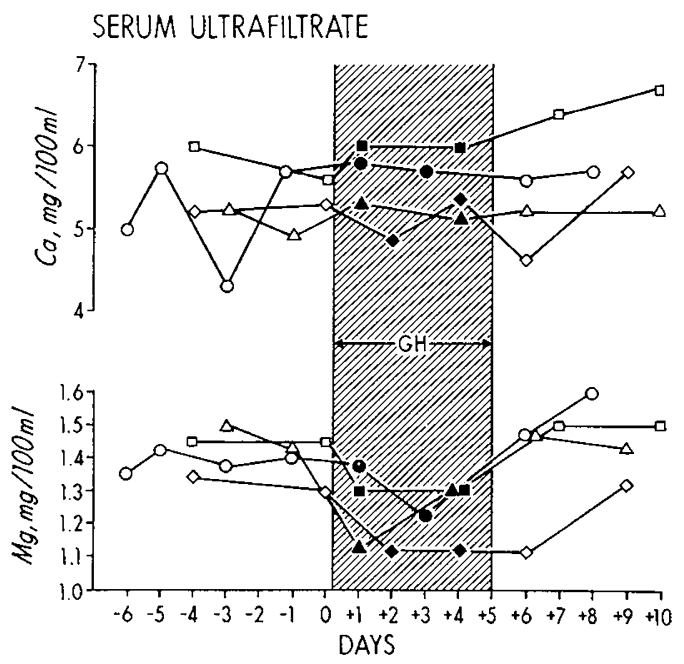

Fig. 4. Serial values for ultrafiltrable $\mathrm{Ca}$ and $\mathrm{Mg}$ in serum before, during, and after $\mathrm{GH}$ treatment in four subjects. $\bigcirc$ : Control periods. : GH period. 
Table IV. Patienıs with hypoparathyroidism, urine excretion (averages)

\begin{tabular}{|c|c|c|c|c|c|c|c|}
\hline Subject & Days & Period & $\mathrm{Ca}, \mathrm{mg} / 24 \mathrm{hr}$ & $\mathrm{P}, \mathrm{mg} / 24 \mathrm{hr}$ & $\mathrm{Sr}, \mu \mathrm{g} / 24 \mathrm{hr}$ & Serum $\mathrm{Ca}, \mathrm{mg} / 100 \mathrm{ml}$ & Present treatment \\
\hline & 4 & $\mathrm{GH}, 5 \mathrm{mg} / 24 \mathrm{hr}$ & 243 & 808 & & & $\begin{array}{l}\text { Ca gluconate, dihy- } \\
\text { drotachysterol, ar- } \\
\text { tane }\end{array}$ \\
\hline \multirow[t]{2}{*}{$T B$ (11 yrs) } & 5 & Control & 403 & 720 & 77 & $10.0,10.2$ & \multirow{2}{*}{$\begin{array}{l}\text { Ca gluconate, vita- } \\
\text { min D }\end{array}$} \\
\hline & 5 & $\mathrm{GH}, 5 \mathrm{mg} / 24 \mathrm{hr}$ & 573 & 801 & 140 & $10.2,10.3$ & \\
\hline $\begin{array}{l}D D \quad(2 \text { yrs, } 10 \\
\text { mos) }\end{array}$ & 7 & Control & 17 & 261 & & $\begin{array}{l}9.2,9.4,9.0,9.2 \\
9.0\end{array}$ & $\begin{array}{l}\text { Dilantin, phenobarbi- } \\
\text { lal, vitamin D }\end{array}$ \\
\hline
\end{tabular}

and $\mathrm{GH}$ periods were made on six subjects. BMR increased by $8-39 \%$ in three of the subjects, while the change was minimal in the other three $(3-6 \%)$. There was no correlation $(r-0.18)$ between the rise in BMR and the increment in urine Ca.

Creatinine clearance. Daily urines were analyzed for this substance, and serum creatinine was determined every few days. The average daily creatinine clearance for the GH period was compared with the average for the immediately preceding control period. The response ranged from a decrease of $13 \%$ to an increase of $56 \%$, the average for the entire group being $+14 \%$.

A plot of the change in creatinine clearance versus change in urine Ca excretion revealed no evidence for a relationship between these two variables $(r+0.15)$.

Effects of $G H$ in patients with hypoparathyroidism. These patients were maintained on their usual dose of vitamin $\mathrm{D}$, or dihydrotachysterol, and $\mathrm{Ca}$ supplements through the study period. The changes in urinary excretion of $\mathrm{Ca}$ and $\mathrm{P}$ associated with $\mathrm{GH}$ administration are depicted in Table IV. Both the adult and the older child responded with increases in $\mathrm{Ca}$ in urine, while the young child reacted in the opposite manner, in that both urine and serum Ca declined. It is also of interest that urine $\mathrm{Sr}$ increased in the one patient in whom this element was assayed.

\section{Discussion}

Although our data do not reveal a definitive etiology for the hypercalcuria which accompanies the administration of growth hormone, they do provide evidence which speaks against certain suggested mechanisms.

First, the data speak against an increase in gastrointestinal absorption as a cause. Some of our subjects sustained an increase in fecal Ca when GH was given, others a decrease; in 5 of the 12 subjects the changes were insignificant. There was no relationship between the changes in the levels of $\mathrm{Ca}$ in urine and in feces in this group of subjects (Fig. 1). As further evidence, it may be noted that urine $\mathrm{Ca}$ also increased in three subjects maintained on a very low Ca diet; in two of these the daily excretion rose to values approximating the dietary intake.

Shepard et al. [31] and Henneman et al. [14] were among the first to claim that the hypercalcuria was due to increased gastrointestinal absorption. But there are conflicting reports in the subsequent literature. Ikkos et al. [18] studied four adult subjects; three showed an increase in fecal $\mathrm{Ca}$ in response to $\mathrm{GH}$ administration, and one a decrease. Schwartz et al. [30] found insignificant changes in three adults. Vest et al. [36] reported a decline in fecal $\mathrm{Ca}$ in two young infants. Forbes et al. [10] reported a "slight" decrease in one subject, and no change in a second. Hanna et al. [13] also found a slight decrease. Elsair et al. [6] studied four children; fecal Ca decreased in one subject and increased in one, while the other two showed an insignificant change.

Second, our experiences with patients who were diagnosed as having idiopathic hypoparathyroidism make it unlikely that the parathyroid glands are involved in mediating the hypercalcuria. Both of our older subjects had hypercalcuria in response to $\mathrm{GH}$ administration in the absence of a significant change in serum $\mathrm{Ca}$, as did a hypoparathyroid patient studied by Hernandez et al. [16]. On the other hand, two patients studied by Schwartz et al. [30] did not show an effect.

Our third patient, a child of $210 / 12$ years who has the congenital rubella syndrome, manifested a decrease in both urine and fecal $\mathrm{Ca}$, and a slight decrease in serum Ca. The reason for his aberrant behavior is not known: perhaps the anticonvulsant medication interfered in some manner with calcium metabolism, as has been reported in other patients on such medication [5, $20,26]$; or perhaps the stimulus to bone growth in this young subject was sufficient to overwhelm the mecha- 
nisms, whatever they may be, responsible for the usually observed hypercalcuria. In this respect the data of Vest et al. [36] are of interest, for four of the seven young infants and children (with presumably intact parathyroid function) studied by them showed a decrease in urine Ca excretion. On the other hand, Hernandez et al. [16] found that the young children whom they studied had increments in urine $\mathrm{Ca}$ comparable to that of older children.

Third, the possibility that hypercalcuria is secondary to a change in the level of ultrafiltrable $\mathrm{Ca}$ in serum is excluded by the data presented in Figure 4, which show no evidence for a consistent change in this component of serum in response to $\mathrm{GH}$ administration. Of incidental interest is the fact that serum ultrafiltrable $\mathrm{Mg}$ declined in each of the four subjects in whom these assays were done; so too did total serum $\mathrm{Mg}$.

A fourth possibility is that the hypercalcuria is incidental to a GH-induced enhancement of thyroid function. Basal metabolic rate does rise in some subjects, but not in all [2, 14, 24]; some authors report slight increases in serum PBI, others no change [14, 17, 39]; radioiodine uptake in the thyroid does not change [14, 39]. The subjects studied by Prader et al. [24] had hypercalcuria in the absence of a rise in BMR, and we could not demonstrate a quantitative relationship between the rise in BMR and the rise in urine $\mathrm{Ca}$ in our subjects. Evans et al. [7] found a rise in metabolic rate when $\mathrm{GH}$ was given to hypophysectomized-thyroidectomized rats. The fact that urine $\mathrm{P}$ and $\mathrm{Mg}$ tend to diminish during GH administration also speaks against hyperfunction of the thyroid as a cause for hypercalcuria.

It is possible, of course, that the growth hormone preparations used by some investigators may have been contaminated with appreciable amounts of thyroid stimulating hormone.

Other possibilities which appear to be excluded are the influence of alterations in urinary $\mathrm{Na}$ excretion, as suggested by Sotos [34], and of changes in renal function. Our data failed to reveal a relationship between the magnitude of the decrease in $\mathrm{Na}$ and the increase in $\mathrm{Ca}$ in urine $(r-0.20)$. Moreover, excretion of $\mathrm{Na}$ in urine returned to base line values much more quickly (1st day) than did that of $\mathrm{Ca}$ (3rd to 5 th day) after $\mathrm{GH}$ was discontinued.

We found, as have others $[3,12]$, that renal function often increases when $\mathrm{GH}$ is given, but in four of our subjects the rise in $\mathrm{Ca}$ excretion did not begin until the 2nd day of GH therapy whereas the rise in creati- nine clearance invariably occurred on the 1st day. Furthermore, there was no evidence for a quantitative relation between the change in creatinine clearance and the change in urine $\mathrm{Ca}$ among our subjects. Prader et al. [24] observed hypercalcuria in the face of a slight decline in creatinine clearance. These observations speak against altered renal function as a cause.

Some observers $[6,15]$ have reported an increase in urine citrate and $\alpha$-ketoglutarate, and an increase in serum citrate in response to $\mathrm{GH}$ administration; in the absence of further evidence the relationship between these changes and that of urine Ca must remain conjectural.

All things considered, the most likely possibility is that the hypercalcuria is a manifestation of the action of GH (or perhaps "sulfation factor" [4], an unidentified plasma component which increases the incorporation of radiosulfur in cartilage) on bone itself. This idea receives support from our observations of an increase in urine Ca in the face of a low Ca diet, and the increase in urine excretion of three bone seekers: $\mathrm{Sr}$, $\mathrm{Pb}$, and $\mathrm{F}$. Abramow and Corvilian [1] also found an increase in urine $\mathrm{Pb}$ in two adult patients. The increase in hydroxyproline excretion which we and others $[28,30,39]$ have observed is in keeping with this idea. Furthermore, some patients with acromegaly have hypercalcuria and exhibit areas of osteoporosis [34].

Growth hormone is known to affect the histologic appearance of cartilage when given to hypophysectomized animals: cartilage proliferation is enhanced, and there is an increase in thymidine labeling of cell nuclei [19]. The incorporation of sulfur and proline into cartilage is increased. True bone growth occurs with long term administration.

In some preliminary experiments [8] the osteoprogenitor cells of the metaphysis and the osteoblast precursor cells (terminology of Owen [23]) of the diaphysis both showed an increase in ${ }^{3} \mathrm{H}$-thymidine labeling when large doses of the hormone were given to young intact rabbits and to hypophysectomized rats. Although there was no evidence for an increase in the number of osteoclasts, it is probable that some of the metaphyseal osteoprogenitor cells possess osteoclastic potential.

Although the evidence which can be brought to bear on this question is circumstantial in nature, one cannot dismiss the postulate that GH has an initial osteolytic effect. The precise nature of this effect remains to be found. Perhaps the hormone stimulates the activity of the bone remodeling process to a greater extent 
than it stimulates the processes of enchondral ossification, so that $\mathrm{Ca}$ and other bone seekers are temporarily lost from the skeleton in the initial period of therapy.

\section{Summary}

A study of the metabolic response to growth hormone administration was made in 12 children given the hormone because of short stature, with particular reference to the occurrence of hypercalcuria. Ten of the subjects had hypercalcuria, including three who were given a low calcium diet. The urinary excretion of $\mathrm{N}$, $\mathrm{P}, \mathrm{K}, \mathrm{Na}$, and $\mathrm{Cl}$ decreased. Serum $\mathrm{Ca}$ did not change, nor were there consistent changes in fecal Ca.

Hypercalcuria was associated with an increase in the urinary excretion of $\mathrm{Sr}, \mathrm{Pb}, \mathrm{F}$, and hydroxyproline. Changes in $\mathrm{Mg}$ excretion were minimal though serum $\mathrm{Mg}$ fell. The magnitude of the hypercalcuria could not be correlated with changes in BMR or changes in creatinine clearance.

It is apparent that those elements whose principal site of residence is in bone are excreted in greater quantities when growth hormone is given, whereas those which are located primarily in nonskeletal tissue are retained.

Three patients with idiopathic hypoparathyroidism were also studied; two of these had hypercalcuria.

These observations suggest that the hormone stimulates bone resorption, either directly or via sulfation factor.

\section{References and Notes}

1. Abramow, M., and Corvilain, J.: Effets métaboliques de l'hormone de croissance humaine chez l'adulte et l'enfant. Ann. Endocrinol., 24: 145 (1967).

2. BRAY, G. A.: Calorigenic effect of human growth hormone in obesity. J. Clin. Endocrinol., 29: 759 (1959).

3. Corvillain, J., and ABramow, M.: Some effects of human growth hormone on renal hemodynamics and on tubular phosphate transport in man. J. Clin. Invest., 41: 1230 (1962).

4. Daughaday, W. H., and KipNis, D. M.: The growth-promoting and anti-insulin actions of somatotropin. Recent Progr. Hormone Res., 22: 49 (1966).

5. Dent, C. E., Richens, A., Rowe, D. J. F., And Stamp, T. C. B.: Osteomalacia with long-term anticonvulsant therapy in epilepsy. Brit. Med. J., f: 69 (1970).

6. Elsair, J., Grrbeaux, S., Dartors, A. M., and Royer, P.: Effets de l'hormone de croissance dans le manisme hypothalamo-hypophysaire. Rev. Fr. Etud. Clin. Biol., 9: 287 (1964).

7. Evans, E. S., Simpson, M. E., and Evans, H. M.: The role of growth hormone in calorigenesis and thyroid function. Endocrinology, 63: 836 (1958).

8. Forbes, G. B.: Unpublished.
9. Forbes, G. B., Bryson, M. F., Reina, J. C., And Smith, F. A.: Metabolic response to growth hormone administration. Abstracts 2nd Internat. Symp. on Growth Hormone, Excerpta Med., p. 59 (1971).

10. Forbes, A. P., Jacobsen, J. G., Carroll, E. L., and Pechet, M. M.: Studies of growth arrest in gonadal dysgenesis: response to exogenous human growth hormone. Metabolism, 11: 56 (1962).

11. Fraser, R., and Harrison, M.: The effect of growth hormone on urinary calcium excretion. Ciba Found. Colloq. Endocrinol., 13: 135 (1960).

12. GershberG, H.: Metabolic and renotropic effects of human growth hormone in disease. J. Clin. Endocrinol., 20: 1107 (1960).

13. Hanna, S., Harrison, M. T., Macintyre, I., and Fraser, R.: Effects of growth hormone on calcium and magnesium metabolism. Brit. Med. J., 2: 12 (1961).

14. Henneman, P. H., Forbes, A. P., Moldawer, M., Dempsey, E. F., AND Carroll, E. L.: Effects of human growth hormone in man. J. Clin. Invest., 39: 1223 (1960).

15. Henneman, D. H., and Henneman, P. H.: Effects of human growth hormone on levels of blood and urinary carbohydrate and fat metabolites in man. J. Clin. Invest., 39: 1239 (1960).

16. Hernandez, G. R., Balsan, S., and Royer, P.: Action de l'hormone de croissance humaine sur la calciurie. Ann. Pediat., 43: 298, 307 (1967).

17. Hutchings, J. S., Escamilla, R. F., Deamer, W. C., and Lr, C. H.: Metabolic changes produced by human growth hormone (Li) in a pituitary dwarf. J. Clin. Endocrinol., 19: 759 (1959).

18. Ikkos, D., Luft, R., and Gemzell, C. A.: The effect of human growth hormone in man. Acta Endocrinol., 32: 341 (1959).

19. Kember, N. F.: Cell population kinetics of bone growth. Clinical Orthop. Related Res., 76: 213 (1971).

20. KRUSE, R.: Osteopathien bei antiepileptischer Langzeittherapie (Forläufige Mitteilung). Monatsch. Kinderh., 116: 378 (1968).

21. Laron, Z., Pertizelan, A., Karp, M., Kowaldo-Silbergeld, A., And Daughaday, W. H.: Administration of growth hormone to patients with familial dwarfism with high plasma immuno-reactive growth hormone: measurement of sulfation factor, metabolic and linear growth responses. J. Clin. Endocrinol. Metab., 33: 332 (1971).

22. Lipsett, M. B., Bergenstal, D. M., and Dhyse, F. G.: Metabolic studies with human growth hormone in dwarfism and acromegaly. J. Clin. Endocrinol., 21: 119 (1961).

23. OWEn, M.: The origin of bone cells. Int. Rev. Cytol., 27. 213 (1969).

24. Prader, A., Zachmann, M., Poley, J. R., and Illig, R.: The metabolic effect of a small uniform dose of human growth hormone in hypopituitary dwarfs and in control children. Acta Endocrinol., 57: 115 (1968).

25. Prockop, D. J., And Udenfriend, S.: A specific method for the analysis of hydroxyproline in tissues and urine. Anal. Biochem., 1: 228 (1960).

26. Richens, A., ANd Rowe, D. J. F.: Disturbance of calcium metabolism by anticonvulsant drugs. Brit. Med. J., 4: 73 (1970).

27. Root, A. W., ANd Oski, F. A.: Effects of human growth hormone in elderly males. J. Gerontol., 24: 97 (1969). 
28. SAIro, S.: Metabolic effects of growth hormone and mode of its action on protein metabolism. Folia Endocrinol. Jap., 43: 701 (1967).

29. Schwartz, E., Echemendia, E., Schiffer, M., and Panariello, V. A.: Mechanism of estrogenic action in acromegaly. J. Clin. Invest., 48: 260 (1969).

30. Schwartz, E., Wiedemann, E., Simon, S., and Schiffer, M.: Estrogenic antagonism of metabolic effects of administered growth hormone. J. Clin. Endocrinol., 29: 1176 (1969).

31. Shepard, T. H., Nielsen, R., Johnson, M., and Bernstein, N.: Human growth hormone. Amer. J. Dis. Child., 99: 74 (1960).

32. SMIтH, F. A.: Metabolism of inorganic fluoride. In: Handbook of Experimental Pharmacology, Vol. 20/1, p. 53. (Springer-Verlag, New York, 1966).

33. SMITH, F. A., AND Gardner, D. E.: The determination of fluoride in urine. Amer. Ind. Hyg. Ass. Quart., 16: 215 (1955).

34. Sotos, J. F.: Gigantism and acromegaly. In: L. I. Gardner: Endocrine and Genetic Diseases of Childhood, p. 142. (Saunders, Philadelphia, 1969).

35. Toribara, T. Y., Terepka, A. R., And Dewey, P.: The ultrafiltrable calcium of human serum. I. Ultrafiltration methods and normal values. J. Clin. Invest., 36: 738 (1957).

36. VeSt, M., Girard, J., AND BüHLER, U.: Metabolic effects of short term administration of growth hormone in infancy and early childhood. Acta Endocrinol., 44: 613 (1963).

37. Villee, D. B., Nichols, G., JR., and Talbot, N. B.: Metabolic studies in two boys with classical progeria. Pediatrics, 43: 207 (1969).

38. Widdowson, E. M., And Dickerson, J. W. T.: Chemical composition of the body. In: C. L. Comar and F. Bronner: Chemical Composition of the Body, Vol. II A, p. 1. (Academic Press, New York, 1964).
39. Wright, J. C., Brasel, J. A., Aceto, T., JR., Finkelstein, J. W., Kenny, F. M., Spaulding, J. S., and Blizzard, R. M.: Studies with human growth hormone (HGH). Amer. J. Med., 38: 499 (1965).

40. Human growth hormone was kindly supplicd by National Pituitary Agency, and National Institute of Arthritis and Metabolic Diseases.

41. Autoanalyzer, Technicon Corporation, Tarrytown, N. Y.

42. Informed consent was obtained from these subjects and their parents.

43. Some of these analyses were performed by Mr. Phillip Robbins, Bureau of Radiological Health, United States Department of Health, Education, and Welfare, Cincinnati, Ohio.

44. Dr. Luville Steadman, Department of Radiation Biology, University of Rochester, Rochester, N.Y.

45. Dr. Frank A. Smith, Department of Radiation Biology, University of Rochester, Rochester, N.Y.

46. Dr. G. B. Forbes is the recipient of a Research Career Award from the National Institutes of Health.

47. The present address of Dr. G. H. Amirhakimi is: University of Shiraz, Shiraz, Iran.

48. The present address of Dr. J. C. Reina is: Universidad del Valle, Cali, Colombia.

49. Supported by National Institutes of Health Grants nos. RR00044 (Clinical Research Center) and HD-01144, and by the United States Atomic Energy Project at University of Rochester, Report no. UR 3490-90.

50. Requests for reprints should be addressed to: Michafl F. BRYSON, M.D., Department of Pediatrics, University of Rochester School of Medicine, 260 Crittenden Blvd., Rochester, N. Y. 14642 (USA).

51. Accepted for publication May 30, 1972. 